\title{
ФУНКЦІЇ АНТРОПОНІМІВ У ЛІТЕРАТУРНИХ ТВОРАХ ШКІЛЬНОЇ ПРОГРАМИ: СТАРШІ КЛАСИ
}

\author{
Івахно Н. О. \\ аспірантка кафедри украӥнської літератури, \\ методики ї̈ навчання та журналістики \\ Ніжинський державний університет імені Миколи Гоголя \\ вул. Графська, 2, Ніжин, Чернігівська область, Україна \\ orcid.org/0000-0003-3511-481X \\ ivakhno1996@ukr.net
}

\author{
Ключові слова: \\ художній антропонім, \\ символічність, \\ характеристична функиія, \\ образна функиія, пообразний \\ шлях аналізу.
}

Антропоніми є найбільш кількісною групою літературних онімів, яка відіграє істотну функціональну роль у художньому тексті. Проблема вивчення антропонімів як одного 3 важливих складників твору досить актуальна, оскільки дослідження власних назв тісно пов'язане, насамперед, 3 образним наповненням, сюжетними, композиційними, жанровими та стильовими особливостями тексту, а також дає змогу глибше проаналізувати його на всіх структурних рівнях. Поглиблене дослідження із власними найменуваннями людей у процесі грунтовного дослідження літературного твору потребує спеціальної розробки. Статтю присвячено загальному огляду шкільного вивчення антропонімів у творах української літератури, передбачених навчальною програмою для аналізу в старших класах загальноосвітніх шкіл. Описано погляди дослідників на літературно-художню антропоніміку як особливу галузь ономастики, яка вивчає все різноманіття власних найменувань людей у художній літературі, та наведено різні думки щодо властивостей антропонімів у творах українських письменників. Визначено основні функціональні можливості особових імен, прізвищ та прізвиськ, а також продемонстровано їх на матеріалі літературних антропонімів художніх текстів, рекомендованих для вивчення в старших класах загальноосвітніх шкіл, зокрема детально проаналізовано найбільш продуктивні функції літературно-художніх антропонімів такі, як номінативну, характеристичну, символічну, сюжетно-композиційну, хронотопну, образну, жанрову та стильову. Проаналізовано зв'язок антропонімів з елементами сюжетного, композиційного, часопросторового, образного, жанрового та стильового рівнів літературного твору. Продемонстровано поглиблене вивчення антропонімів у процесі аналізу сюжетно-композиційної, хронотопної організації, характеристики образів-персонажів, дослідженні жанрових та стильових особливостей на матеріалі конкретних прозових текстів для старших класів загальноосвітніх закладів. 


\title{
THE FUNCTIONS OF ANTHROPONYMS IN THE LITERARY WORKS OF THE SCHOOL PROGRAM: SENIOR CLASSES
}

\author{
Ivakhno N. O. \\ Postgraduate Student at the Department of Ukrainian Literature, \\ Methodology of its Teaching and Journalistic \\ Nizhyn Mykola Gogol State University \\ Grafska str., 2, Nizhyn, Chernihiv region, Ukraine \\ orcid.org/0000-0003-3511-481X \\ ivakhno1996@ukr.net
}

Key words:

artistic anthroponym, symbolism, characteristic function, imaginative function, image-by-image way of analysis.
Anthroponyms are the most numerous group of literary onyms which perform the significant functional role in the artistic text. The problem of studying anthroponyms as one of the important components of the work is actual because the research of proper names is closely connected with first of all the imaginative filling, plot, compositional, genre and stylistic features of the text, and also allows to analyze it at all its structural levels deeper. The depth work with people's own names in the process of detailed research of a literary work requires a special development. The article is devoted to the general review of the school study of anthroponyms in the work of Ukrainian literature, which are predicted by the curriculum for the analysis in the senior classes of the secondary school. The researchers' views on literary-artistic anthroponymic as a special section of onomastica that studies all the variety of people's own names in fiction are described, and different opinions about features of anthroponyms in Ukrainian writers' works are given. The main functionalities of personal names, surnames and nicknames are defined, and also they are demonstrated on the material of literary anthroponyms of artistic texts which are predicated for study in senior classes of the secondary school, in particular the most prodactive functions of literary-artistic anthroponyms such as nominative, characteristic, symbolic, plot-composition, chronotopic, imaginative, genretive and stylistic are analyzed. The connection between anthroponyms and elements of plot, compositional, space-temporal, imaginative, genretive and stylistic levels of the literary work is analyzed. The depth study of anthroponyms in the process of the plot-compositional, chronotopic organization analysis, the characterization of characters, the research of genre and stylistic features on the material of specific prose texts for senior classes of secondary schools is demonstrated.
Постановка проблеми. Одним із функціонально важливих складників літературного твору є власна назва, зокрема імена, прізвища, прізвиська персонажів. Проблема вивчення художніх антропонімів у школі актуальна, адже окреслення функціонального навантаження цих онімів сприяє поглибленому аналізу літературного твору крізь призму його образного, сюжетно-композиційного, часопросторового, стильового та жанрового наповнення.

Становлення антропоніміки як окремої галузі розпочалося лише 3 другої половини $\mathrm{XX}$ століття. В уявленні наших предків імена вважалися магічними й захищали носіїв від хвороб, лихого ока та смерті. Наприклад, «даючи ім'я Продан чи Куплен, мати виконувала певний обряд: за суто символічну плату вона продавала своє дитя жінці, в якої діти росли здоровими та не хворіли. Після закінчення обряду продажу дитина знову поверталася у рідну сім'ю» [2].

М. Худаша в монографії «3 історії української антропонімії» зазначає, що основною властивістю онімів $\epsilon$ те, що власні імена $є$ основою для творення прізвищ та прізвиськ [11, с. 38]. Л. Масенко розглядає прізвища, прізвиська як способи ідентифікації людини, тобто робить акцент на номінативній функції [7]. І. Крохмаль говорить про іншу важливу ознаку власних назв - розпізнавальну. Дослідниця вказує на те, що «основним способом ідентифікації особи наприкінці XVIII - початку XIX ст. була двокомпонентна антропонімна структура, до складу якої входили власне ім'я та прізвищева назва» [6, с. 3]. 
Функції власних назв у художній літературі почали досліджувати 3 середини XX ст. М. Торчинський вказує на те, що «спочатку виділяли лише стилістичну функцію, а пізніше - емоційно-стилістичну, естетичну, ідеологічну та багато інших» $[10$, с. 21$]$. Проблема функціональності власних назв у літературі розглядалася в працях Ю. Карпенка, М. Торчинського, Л. Белея, Л. Зеленко, О. Лавер, О. Гогуленко та інших. Особливо активно вивчають антропонімну лексику I. Франка, М. Коцюбинського П. Куліша, Лесі Українки, Миколи Хвильового, В. Винниченка, Ю. Яновського та інших.

Аналіз останніх грунтовних досліджень свідчить, що нині антропоніми всебічно розглянуті 3 погляду їх функціональної ролі в художньому творі, проте методика шкільного вивчення тексту 3 їх урахуванням ще потребує спеціальної розробки.

Антропоніми - найчисельніша група назв, яка має важливе функціональне навантаження в літературному тексті. Мета статті - окреслити функціональне значення літературно-художніх антропонімів на прикладі творів української літератури, передбачених шкільною програмою для вивчення в старших класах.

Виклад основного матеріалу. Серед основних функцій, які виконують антропоніми в художньому тексті, можна назвати номінативну, характеристичну та символічну. Використання антропонімів, насамперед, пов'язане з образами персонажів будь-якого твору: герой, як правило, наділений іменем, яке характеризує його або виступає символом. О. Карпенко переконана, що «письменник добирає імена своїм персонажам, уже обміркувавши їх характер та особливості, знаючи їх роль у розвитку сюжету. Він, на відміну від батьків, що іменують своїх дітей немовлятами, називає вже дорослих, сформованих людей» [5, с. 69-70].

Часто власне найменування вжите автором виключно для номінації. Письменник називає героїв, не пояснюючи й не характеризуючи ім'я. Наприклад, наявність лише прізвищ (Вагман, Брикальський, Баран, Шнадельський, Шварц, Кшивотульський, о. Зварич, о. Семенович) у персонажів роману I. Франка «Перехресні стежки» вказує на те, що митець «очевидно, вбачає важливість цих героїв тільки в їх посадах» [4, с. 71].

Саме завдяки характеристичній функції художні антропоніми відрізняються від реальних імен. О. Слоньовська переконана, що «своїм літературних героям імена письменник обирає $<\ldots>$ не маючи уявлення, що $<\ldots>$ ім'я означає в перекладі, зате завжди ліпить характер, який унікально відповідає імені героя» [9, с. 201].

Ще одна властивість особових імен - їхня символічність. Л. Белей переконаний, що персона- жів-проповідників у художніх творах називають часто апостольськими та євангелістськими іменами. Дослідник наводить прізвище Адаменко 3 роману в новелах Ю. Яновського «Вершники» та ім'я Андрій, яке «після «Тараса Бульби» М. Гоголя набуло репутації зрадницького» [1].

Антропонім Олена в повісті О. Кобилянської «Людина» характеризує героїню: 3 грецької ім'я означає «сонячне світло», «смолоскип» або «та, що несе світло» [8, с. 169]. Тому десятикласники визначають символічність образу: Олена-це переосмислення авторкою-феміністкою ролі жінки в суспільстві.

Антропоніми як необхідний елемент будьякого твору тісно пов'язані з його складниками (насамперед сюжетом, композицією, хронотопом та образами) і властивостями (жанром, стильовою домінантою). Відповідно, визначаємо, що найпродуктивнішими для власних особових найменувань у художньому тексті можуть бути такі функції, як сюжетно-композиційна, хронотопна, образна, жанрова та стильова, які розкриваються в процесі подієвого, пообразного, жанрового та структурно-стильового шкільних аналізів літературного твору.

Найпоширенішою серед художніх антропонімів є образна функція. Ім'я створює героя, адже зазвичай це перше, що читач дізнається про нього. Антропонім також є одним 3 елементів портретної характеристики. У драмі ім'я та соціальний статус героя подані вже в переліку дійових осіб. Ім'я персонажа як засіб його творення - важлива складова частина стандартної літературознавчої схеми в процесі пообразного аналізу [3, с 68]. Ю. Бондаренко переконаний, що «це стосується тих випадків, коли номінація досить прозоро відображає психологічний потенціал героя, його ключові риси. Так, схильність до накопичення, що асоціюється із процесом розширення, надування, пов'язана з прізвищем Пузир (комедія Івана Карпенка-Карого «Хазяїн») [3, с. 71].

Власна назва іноді може бути промовистою 3 огляду на походження, соціальний статус чи род зайнятості персонажа. У художній літературі прізвища на -ський вживаються для називання персонажів шляхетного, аристократичного походження (наприклад, заможні шляхтичі Красовський і Гуляницький із трагікомедії «Мартин Боруля»). Прізвисько Косар у кіноповісті О. Довженка «Зачарована Десна» характеризує свого носія через рід його діяльності: «Він був такий великий косар, що сусіди забули навіть його прізвище і звали його Самійло-косар, а то й просто Косар».

На сюжетно-композиційному рівні можна простежити зв'язок антропонімів із розвитком подій або композицією твору. Наприклад, пріз- 
вище Боруля із трагікомедії Івана Карпенка-Карого «Мартин Боруля» $\epsilon$ своєрідним центром, навколо якого відбуваються основні сюжетні події й загалом організована художня структура тексту. Зокрема, цей антропонім також виконує проблемно-тематичну функцію, адже головна проблема драми - ономастична, пов'язана з бажанням змінити просте прізвище на дворянське. Сюжетну роль виконують також чоловічі антропоніми в новелі I. Франка «Сойчине крило», адже кожен пов'язаний із новою сюжетною подією в житті головної героїні Мані, та прізвисько Переломаний (новела В. Стефаника «Камінний хрест»), яке сам автор пояснює через сюжетний епізод про важку роботу Івана Дідуха на горбі, котрий і підірвав його здоров'я.

Власні назви часто впливають і на часопростір літературного тексту. Хронотопну функцію виконують, наприклад, прізвища Марічки та Івана із повісті М. Коцюбинського «Тіні забутих предків»: характерні для західноукраїнського антропонімікону суфікси -ук-, -юк- в антропонімах Палійчук і Гутенюк локалізують місце, в якому відбуваються події, - Гуцульщина.

Вибір найменувань персонажів може залежати від жанру та стилю твору, в якому вони діють. Антропоніми роману Ю. Яновського «Майстер корабля» виконують жанрову й стильову функції, адже автор використовує екзотичні імена для своїх героїв, що $\epsilon$ рисою неоромантичної літератури. У романі взагалі немає прізвищ, а всі імена - безваріантні, незмінні, що відповідає поетиці романтичного напряму. Антропоніми історичних героїв Богдана Хмельницького та Байди
Вишневецького в романі у віршах «Марусі Чурай» Л. Костенко виконують жанрову роль: імена гетьманів створюють колорит епохи, адже за жанром це історичний роман у віршах.

Яскравим прикладом стильової функції є імена героїв повісті Івана Нечуя-Левицького «Кайдашева сім'я» та роману Панаса Мирного та Івана Білика «Хіба ревуть воли, як ясла повні?». Спираючись на народницьку традицію, письменники-реалісти називають персонажів реальними іменами із сільського антропонімікону.

Висновки. Основна функція антропонімів, як і будь-якої іншої групи власних назв, номінативна. Головне призначення особового найменування -назвати й охарактеризувати героя за допомогою імені.

Антропоніми в художніх творах мають важливе функціональне навантаження. Вони пов'язані майже з усіма елементами художнього твору, тому серед найпродуктивніших функцій літературних особових назв можна виділити такі: сюжетно-композиційна (імена тісно пов'язані 3 розвитком подій та художньою структурою тексту загалом), хронотопна (антропоніми впливають на часопросторову організацію твору), образна (ім'я персонажа - засіб його характеристики), жанрова та стильова (власні назви героїв пов'язані з жанровою та стильовою домінантою твору).

Отже, художні найменування людей вирізняються функціональністю в літературі. Поглиблений аналіз антропонімів варто здійснювати в процесі, насамперед, пообразного, а також подієвого, композиційного, хронотопного, жанрового та структурно-стильового аналізів твору.

\section{Література}

1. Белей Л. Літературно-художні імена-символи. Культура слова. 1996. Випуск 46-47. С. 63-67.

2. Белей Л. Ім’я дитини в українській родині. Харків : Фоліо, 2010. 282 с.

3. Бондаренко Ю. Вивчення образів-персонажів літературного твору в школі: теорія і практикум : посібник для студентів філолологічного факультету. Ніжин : НДУ ім. М. Гоголя, 2015. 216 с.

4. Бук С. Онімний простір роману Івана Франка «Перехресні стежки». Ономастичні науки. 2012. № 4. C. $68-76$.

5. Карпенко О. Про літературну ономастику та її функціональне навантаження. Записки з ономастики. Випуск 4. URL: http://karpenko.in.ua/wpcontent/uploads/2013/02/Karpen4.pdf.

6. Крохмаль І. Українські прізвища як культурно-мовне явище. Вивчаємо українську мову $і$ літераmypy. 2006. № 15. С. 2-4.

7. Масенко Л. Українські імена і прізвища. Київ : Знання, 1990. 48 с.

8. Скрипник Л., Дзятківська Н. Власні імена людей: Словник-довідник. Київ : Наукова думка, 2005. $335 \mathrm{c}$.

9. Слоньовська О. Слід невловимого Прометея (Міф України в літературі української діаспори 20-х 50-х років XX століття) : монографія. Вид. 2-ге. Івано-Франківськ : Плай; Коломия : Вік, 2007. 688 с.

10. Торчинський М. Структура онімного простору української мови. Частина II: Функціонування власних назв : монографія. Хмельницький : ХНУ, 2009. 394 с.

11. Худаш М. 3 історії української антропонімії. Київ : Наукова думка, 1977. 235 с. 


\section{References}

1. Belei, L. (1996) Literaturno-khudozhni imena-symvoly [Literary-artistic names-symbols]. Kultura slova. Vol. 46-47. P. 63-67.

2. Belei, L. (2010) Imia dytyny v ukrainskii rodyni [Name of a child in Ukrainaian family]. Kharkiv: Folio. 282 p.

3. Bondarenko, Y. (2015) Vyvchennia obraziv-personazhiv literaturnoho tvoru v shkoli: teoriia i praktykum: posibn. dlia studentiv filolohichnoho fakultetu [The study of images-characters of a literary work at school: theory and practice: a manual for students od philological faculty] Nizhyn. 216 p.

4. Buk, S. (2012) Onimnyi prostir romanu Ivana Franka «Perekhresni stezhky» [The onomastic space of Ivan Franko's novel "Crossroads"]. Onomastychni nauky. Vol. 4. P. 68-76.

5. Karpenko, O. Pro literaturnu onomastyku ta yii funktsionalne navantazhennia [About literary onomastic and its functional filling]. Zapysky $z$ onomastyky. Vol. 4. URL: http://karpenko.in.ua/wpcontent/ uploads/2013/02/Karpen4.pdf.

6. Krohmal, I. (2006) Ukrainski prizvyshcha yak kulturno-movne yavyshche [Ukrainian surnames as a cultural-linguistic phenomenon]. Vyvchaiemo ukrainsku movu i literature. Vol. 15. P. 2-4.

7. Masenko, L. (1990) Ukrainski imena i prizvyshcha [Ukrainian names and surnames]. Kyiv: Znannia. 48 p.

8. Skrypnyk, L., Dziatkivska, N. (2005) Vlasni imena liudei: slovnyk-dovidnyk [People's proper names: dictionary-reference book]. Kyiv: Naukova dumka. 335 p.

9. Slonovska, O. (2007) Slid nevlovymoho Prometeia (Mif Ukrainy v literaturi ukrainskoi diaspory 20-kh 50-kh rokiv XX stolittia): monografia [The trace of intangible Prometheus (The myth of Ukraine in the literature of Ukrainian diaspora of the 20-s - 50-s years of XX century): a monograph]. Vyd. 2. Ivano-Frankivsk: Plai; Kolomyia: Vik. 688 p.

10. Torchynskyi, M. (2009) Struktura onimnoho prostoru ukrainskoi movy. Chastyna II: Funktsionuvannia vlasnyh nazv: monografia [The structure of Ukrainian language onymous space: Part II: The functioning of proper names: a monograph]. Khmelnytskyi. 394 p.

11. Khudash, M. (1977) Z istorii ukrainskoi antroponimii [From the history of Ukrainian anthroponomy]. Kyiv: Naukova dumka. 235 p. 